\title{
Orta Karadeniz'de Avlanan Lüfer (Pomatamus saltatrix L., 1766) Balığının Et Verimi ve Kimyasal Kompozisyonu
}

\section{Serap SAMSUN}

Ordu Üniversitesi, Fatsa Deniz Bilimleri Fakültesi, Fatsa, Ordu.

Geliş : :07.11.2016

Kabul : 01.06.2017

Sorumlu Yazar: serapsamsun@hotmail.com

Araştırma Makalesi / Research Paper

E-Dergi ISSN: 1308-7517

Özet

$\mathrm{Bu}$ çalışma, Orta Karadeniz'de avlanan lüfer (Pomatamus saltatrix L., 1766) balığının et verimi ve kimyasal kompozisyonunun belirlenmesi amacıyla yapılmıştır. Araştırmada toplam 96 balık örneği kullanılmıştır. Balıkların toplam boyları 13,2-21,7 cm, toplam ağırlıkları 23,21-88,19 g arasında dağılım göstermiştir. Çalışmada kullanılan lüfer balıklarının ortalama et verimi dişi, erkek ve dişi+erkek için sırasıyla $\% 72,93 \pm 0,51, \% 71,96 \pm 1,85$ ve $\% 71,77 \pm 1,12$ olarak tespit edilmiştir. Yapılan kimyasal analizler sonucunda ortalama ham protein, ham yağ, kuru madde, su ve ham kül oranları sırasıly $\% 16,39 \pm 0,23, \% 13,37 \pm 0,09$, $\% 32,80 \pm 0,47, \% 67,20 \pm 0,47$ ve $\% 1,02 \pm 0,04$ olarak belirlenmiştir.

Anahtar kelimeler: Lüfer, Pomatamus saltatrix, Et Verimi, Kimyasal Kompozisyon, Karadeniz

The Determinatin of the Meat Yield and Chemical Composition of Blue Fish (Pomatomus saltatrix L., 1766) Caught in Middle Black Sea

\begin{abstract}
This study was carried out to determine the meat yield and chemical composition of bluefish (Pomatamus saltatrix L., 1766) caught in Middle Black Sea. A total of 96 fish samples were used in this study. Total length and total weight of fishes were in the range of 13.2-21.7 cm, and 23.21-88.19 g respectively. Average meat yield of blue fish were found as $72.93 \pm 0.51 \%, 71.96 \pm 1.85 \%$ and $71.77 \pm 1.12 \%$, for female, male and female+male respectively. The results of chemical analyses showed that in all fish, mean percentage values of crude protein, crude fat, dry matter, moisture and crude ash were $16.39 \pm 0.23 \%, 13.37 \pm 0.09 \%, 32.80 \pm 0.47 \%$, $67.20 \pm 0.47 \%$ and $1.02 \pm 0.04 \%$ respectively.
\end{abstract}

Keywords: Bluefish, Pomatamus saltatrix, Meat Yield, Chemical Composition, Black Sea

\section{GíRiş}

Balık türlerinin, beslenme ve ekonomik bakımından tercihinde önemli rol oynayan, et verimi ve kimyasal yapısı farklılıklar göstermektedir (Erkoyuncu vd., 1994). Besin maddesi içerikleri, duyusal bakımdan et kalitesini etkileyeceği gibi vücut kompozisyonu üzerine de önemli ölçüde katkı sağlar (Yıldız vd., 2000). Balıklarda et verimi, balık türü, beslenme durumu, yaş ve cinsiyete bağlı olarak değişmekle birlikte \%30-60 arasında değişmektedir (Göğüş ve Kolsarıcı, 1992).

Balık eti biyolojik değerliliği yüksek protein, yağ ve yağda çözünen vitaminleri ile dengeli ve yeterli beslenmede önemli rol oynamaktadır. Türe, yaşa, cinsiyete, çevresel faktörlere ve mevsime bağlı olarak değişebilen ana bileşenleri su (\% 50-85), yağ (\% 0,128) ve protein (\% 14-25) ile az miktarda karbonhidrattan (\% 0,3-0,8) ibarettir (Ergül, 1970).

Ekonomik değeri yüksek ve denizlerimizin Pomatomidae familyasına ait tek üyesi olan lüfer balıkları, Karadeniz ile Ege arasında yaptıkları mevsimsel beslenme-üreme göçü 
esnasında, özellikle batı Karadeniz ve Marmara Denizi'nde yoğun olarak avlanmaktadırlar. Lüfer balıkçılığında kullanılan başlıca av araçları olta, gırgır, trol ve uzatma ağlarıdır (Ceyhan ve Akyol, 2006). Ülkemizde lüfer avcılığında, av miktarı bakımından, en yüksek üretim 1982 yılında gerçekleşmiştir (32.184 ton) (FAO, 2000). 1998-2001 y1lları arasındaki üretim miktarları sırasıyla, 1.491,2; 801,4; 773,8; 6.097,6 ton olup 2001 yılındaki toplam lüfer üretimi önceki yılların ortalamasına göre \% 497 oranında artış göstermiştir (Tekinay vd., 2003). 2006 yılında lüfer av miktarı 8.399 ton iken, 2015 yılında üretim miktarı 4.135,7 ton olarak gerçekleşmiştir (TÜİK, 2015).

Ülkemizde lüfer balıkları boy ve ağırlıklarına göre 5 farklı isim almaktadır (Tablo 1). Bunların içinde çinekop olarak adlandırılan ve 10-20 cm boya sahip bireyler en çok avlanılan kısmı oluşturmaktadır.

Tablo 1. Lüfer balıklarının boy ve ağırlıklarına göre isimleri (Gürtan 1959)

\begin{tabular}{ccc}
\hline Boy $(\mathbf{c m})$ & $\begin{array}{c}\mathbf{1} \text { kg'daki balık } \\
\text { sayısı }\end{array}$ & İsim \\
\hline $8-10$ & $20-40$ adet & Defne yaprăg 1 \\
$10-20$ & $12-20$ adet & Çinekop \\
$20-25$ & 8 adet & Sarkanat \\
$25-35$ & 4 adet & Lüfer \\
$35>$ & 1 adet & Kofana \\
\hline \hline
\end{tabular}

Geçmişten günümüze kadar lüfer/çinekop balığına yönelik uygulanan avlanabilir asgari boy sınırlamalarına bakıldığında, 2004-2006 yıllarını kapsayan 36/1 numaralı denizlerde ve içsularda ticari amaçlı su ürünleri avcılığını düzenleyen sirkülerde çinekop için avlanabilir asgari boy $14 \mathrm{~cm}$ olarak belirlenmiştir. 3/1 Numaralı Ticari Amaçlı Su Ürünleri Avcılığını Düzenleyen Tebliğ de (2012-2016 av sezonu için) lüfer balığının asgari avlanabilir boyu $20 \mathrm{~cm}$ iken $4 / 1$ numaralı tebliğde $18 \mathrm{~cm}$ 'ye düşürülmüştür. Göktürk vd. (2017), Aralık ve şubat aylarında aldıkları örneklerin sırasıyla \% 88,88 ve \% 94,44'ünün asgari avlanabilir boyun altında (3/1 numaralı tebliğe göre) satıldığını belirtmişlerdir.

Lüfer balığının balıkçılık biyolojisi ve avcılı̆̆ı ile ilgili birçok çalışma yapılmış olmasına rağmen (Ceyhan ve Akyol 2005; Ceyhan ve Akyol 2006; Özdemir vd. ,2009a; Özdemir vd., 2009b; Sümer vd., 2010; Cengiz vd., 2012; Bal vd., 2015; Ceyhan vd., 2015) et verimi ve kimyasal kompozisyonu üzerine yapılmış fazla çalışma bulunmamaktadır. Su ürünlerinin et oranlarının ve besin değerlerinin bilinmesi tüketici tercihi açısından büyük önem taşımaktadır. Bu çalışmada, ülkemizde özellikle taze olarak tüketilen ve tüketici tercihinde önemli bir yere sahip olan lüfer balıklarının et verimi ve kimyasal bileşiminin belirlenmesi amaçlanmıştır.

\section{MATERYAL ve YÖNTEM}

Araştırma, Aralık 2004-Şubat 2005 tarihleri arasında Orta Karadeniz Bölgesi Samsun ili sularında yürütülmüştür. Araştırma materyalini, ortasu trolü ile avlanan ve lüferin çinekop adı verilen küçük boy ve ağırlıktaki bireyleri oluşturmaktadır.

İncelenen 96 adet bireyin, toplam boyları $0,1 \mathrm{~cm}$ hassasiyetle ölçülmüş, toplam vücut ağırlıkları, kafa, kuyruk yüzgeci, iç organlar (dalak, karaciğer, sindirim sitemi, safra 
kesesi, ovaryumlar) ve karkas et ağırlı̆̆ $0,01 \mathrm{~g}$ hassasiyetli dijital terazide tartılmıştır. Balıkların kafa ve yüzgeçleri kesilip, iç organları çıkarıldıktan sonra geriye kalan kısmı karkas ağırlığı olarak belirlenmiştir. Karkas ağırlığının toplam vücut ağırlığına oranı karkas verimi olarak ifade edilmiştir (Çelikkale vd., 1998).

Kimyasal analizler için, balıkların sırt kısmından alınan et örnekleri homojenize edilerek, ham protein, ham yağ, kuru madde, su ve ham kül miktarları tespit edilmiştir. Ham yağ analizi Soxhlet Metodu ile, ham protein analizi Kjeldahl yöntemiyle, su tayini etüvde $1050 \mathrm{o}$ 'de kurutma ile ve ham kül miktarı ise $550^{\circ} \mathrm{C}$ 'de kül firınında 6 saat yakılarak yapılmıştır (Korkut ve Hoşsu, 1998). Kimyasal analizler 3 paralel olarak yürütülmüşsür.

Ortalama, standart hata, karşılaştırmalar ve regresyonlar Sümbüloğlu ve Sümbüloğlu (2000)'e göre yapılmıştır. Önem seviyesi $\mathrm{P}=0,05$ önem aralığında $\mathrm{t}$ testi ile değerlendirilmiştir.

\section{BULGULAR}

Çalışmada, 53 dişi ve 43 erkek olmak üzere toplam 96 lüfer balığı değerlendirilmiştir. Balıkların boyları 13,2-21,7 cm, ağırlıkları 23,21-88,19 g arasında olup, ortalama boy ve ağırlıkları ise sirasıyla $17,51 \pm 0,15 \mathrm{~cm}$ ve $48,66 \pm 1,25 \mathrm{~g}$ olarak tespit edilmiştir. Pomatamus saltatrix' in cinsiyetlere göre toplam boy ve toplam ağırlıkları ile çeşitli vücut kısımlarına ilişkin veriler Tablo 2'de, vücudun çeşitli kısımlarının toplam vücut ağırlığına oranları ise Tablo 3 'te verilmiştir.

Tablo 2. $P$. saltatrix'in cinsiyetlere göre ortalama total boyları, vücut ağırlığı ve çeşitli vücut kısımlarının ortalama ağırlıkları $( \pm \mathrm{SE})$

\begin{tabular}{lcccccc}
\hline \hline Cinsiyet & $\mathbf{N}$ & $\begin{array}{c}\text { Toplam boy } \\
(\mathbf{c m})\end{array}$ & $\begin{array}{c}\text { Toplam } \\
\text { ağırlık }(\mathbf{g})\end{array}$ & Kafa $(\mathbf{g})$ & $\begin{array}{c}\text { İç organ } \\
(\mathbf{g})\end{array}$ & $\begin{array}{c}\text { Kuyruk y. } \\
(\mathbf{g})\end{array}$ \\
\hline Dişi & 53 & $17,64 \pm 0,20$ & $50,39 \pm 1,81$ & $8,90 \pm 0,33$ & $2,81 \pm 0,21$ & $0,52 \pm 0,03$ \\
Erkek & 43 & $17,33 \pm 0,21$ & $46,39 \pm 1,63$ & $8,09 \pm 0,29$ & $2,75 \pm 0,17$ & $0,54 \pm 0,03$ \\
Genel & 96 & $17,51 \pm 0,15$ & $48,66 \pm 1,25$ & $8,55+0,26$ & $2,79 \pm 0,17$ & $0,52 \pm 0,02$ \\
\hline \hline
\end{tabular}

Tablo 3. $P$. saltatrix'in cinsiyetlere göre çeşitli vücut kısımlarının toplam vücut ağırlığına oranı ve karkas et verimi $(\%),( \pm \mathrm{SE})$

\begin{tabular}{lccccc}
\hline \hline Cinsiyet & $\mathbf{N}$ & $\begin{array}{c}\text { Kafa ağır. } \\
\text { oranı }\end{array}$ & $\begin{array}{c}\text { İç organ ağır. } \\
\text { oranı }\end{array}$ & $\begin{array}{c}\text { Kuyruk yüz. } \\
\text { ağır. oranı }\end{array}$ & $\begin{array}{c}\text { Karkas et } \\
\text { verimi }\end{array}$ \\
\hline Dişi & 53 & $17,81 \pm 0,31$ & $6,16 \pm 0,30$ & $1,12 \pm 0,02$ & $72,93 \pm 0,51$ \\
Erkek & 43 & $17,59 \pm 0,30$ & $6,20 \pm 0,31$ & $1,19 \pm 0,04$ & $71,96 \pm 1,85$ \\
Genel & 96 & $17,69+0,22$ & $6,21 \pm 0,22$ & $1,15 \pm 0,02$ & $71,77 \pm 1,12$ \\
\hline \hline
\end{tabular}

Lüfer balıklarının et verimi \%64,94-\%88,88 arasında değişmekte olup, dişi, erkek ve dişi+erkek olarak sırasıyla $\% 72,93 \pm 0,51, \% 71,96 \pm 1,85$ ve $\% 71,77 \pm 1,12$ şeklinde belirlenmiştir. Karkas etten sonra en büyük kısmı oluşturan kafa, dişi ve erkek bireylerde sirasıyla ortalama $8,90 \mathrm{~g}(\% 17,81 \pm 0,31)$ ve $8,09 \mathrm{~g}(\% 17,59 \pm 0,30)$ olarak belirlenmiştir. İç organ ve kuyruk oranları 2,65-13,49 ve 0,86-1,53 arasında değişmekle birlikte, dişi bireylerde ortalama iç organ ve kuyruk oranları sırasıyla $\% 6,16 \pm 0,30$ ve $\% 1,12 \pm 0,02$; 
erkek bireylerde ise sirasıyla $\% 6,20 \pm 0,31$ ve $\% 1,19 \pm 0,04$ olarak hesaplanmıştır.

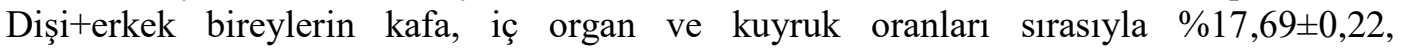
$\% 6,21 \pm 0,22$ ve $\% 1,15 \pm 0,02$ olarak bulunmuştur. Dişi ve erkek lüfer balıklarının, boy, ağırlık, kafa, iç organ, kuyruk ve et oranları arasındaki farklar istatistiki açıdan önemsiz bulunmuştur $(\mathrm{P}>0,05)$.

Balık ağırlığı ile karkas et ağırlığı arasında $\mathrm{y}=0,7521 \mathrm{x}-0,8774(\mathrm{r}=0,98)$, balık ağırlığ1 ile kafa ağırlığ 1 arasında $\mathrm{y}=0,158 \mathrm{x}+0,8628 \quad(\mathrm{r}=0,88)$ şeklinde yüksek korelasyonlu doğrusal ilişkiler bulunurken; balık boyu ile karkas et ağırlığ $\mathrm{y}=0,0051 x 3,0867$ ( $\mathrm{r}=0,84)$, balık boyu ile kafa ağırlığ 1 arasında $\mathrm{y}=0,0035 \times 2,7141 \quad(\mathrm{r}=0,88)$, şeklinde yüksek korelasyonlu üssel ilişkiler belirlenmiştir ( $\mathrm{x}=$ Balık ağırlığı ve balık boyu, $\mathrm{y}=$ karkas et ağrılığ1 ve kafa ağırlı̆̆ $)$ (Şekil 1).
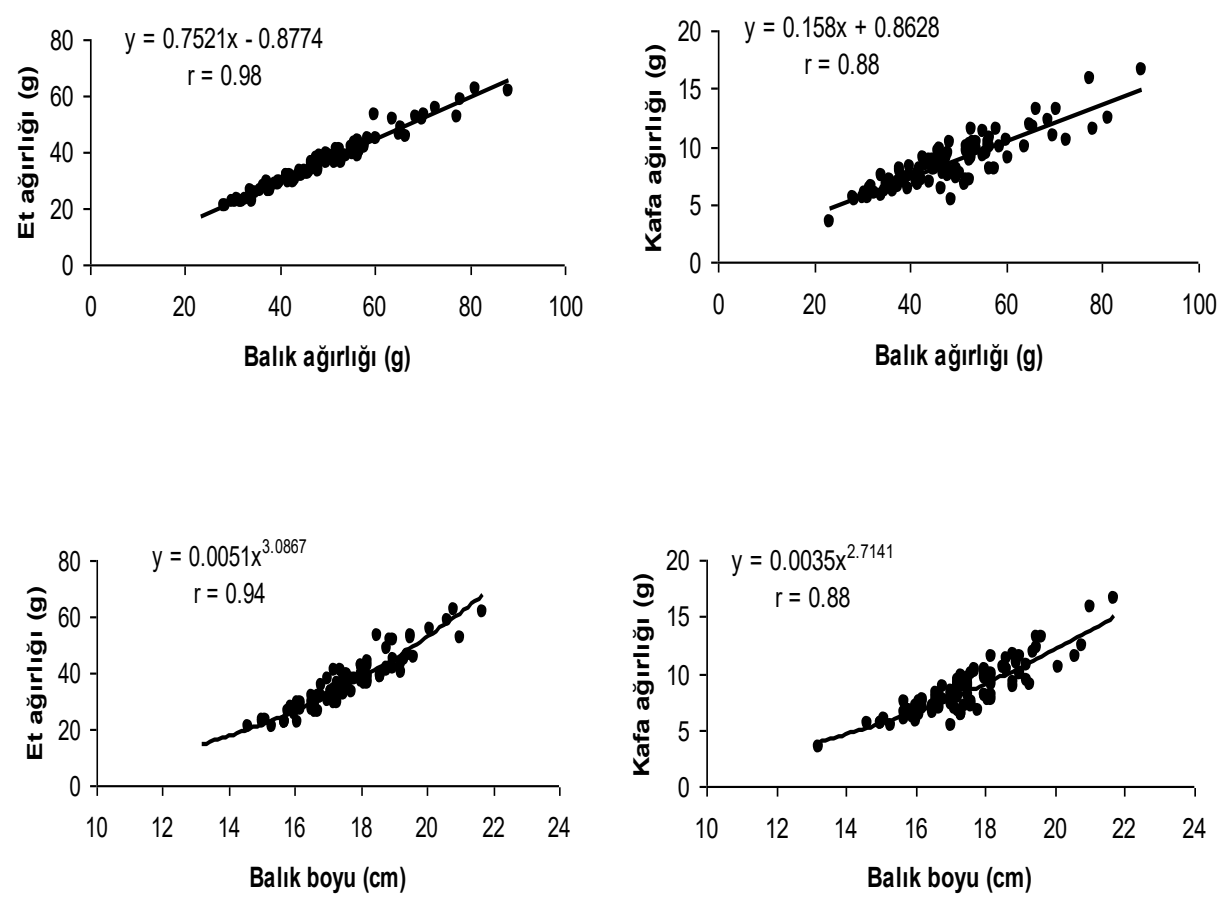

Şekil 1. $P$. saltatrix’ in balık ağırlığının et ağırlığı ve kafa ağırlığı; balık boyunun et ağırlığı ve kafa ağırlı̆̆ ilişkileri

P. saltatrix' in kimyasal kompozisyonu Şekil 2'de verilmiş olup, yaş ağırlıkta yapılan kimyasal analiz sonuçlarına göre ortalama olarak \%16,39 $\pm 0,23$ ham protein, $\% 13,37 \pm 0,09$

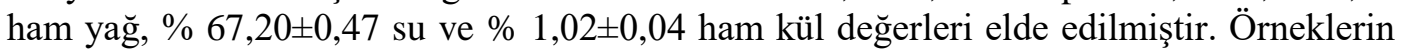

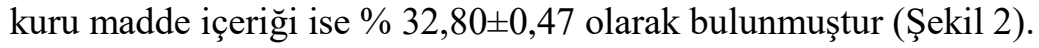




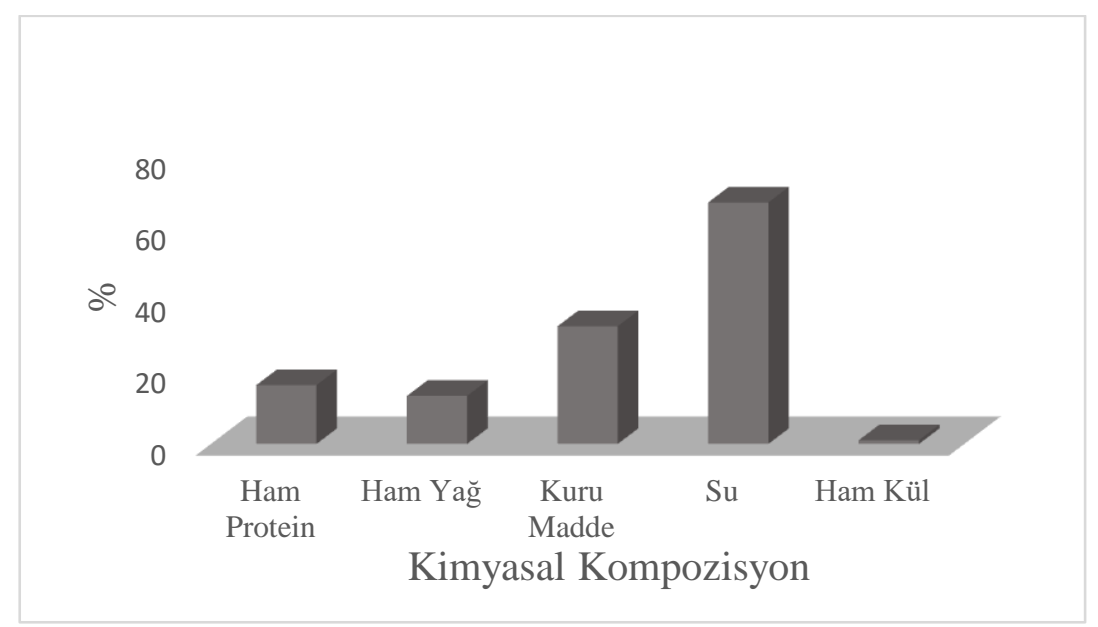

Şekil 2. $P$. saltatrix'in ham protein, ham yağ, kuru madde, nem ve ham kül oranları

\section{TARTIŞMA VE SONUÇ}

Araştırmada incelenen 96 adet $P$. saltatrix bireyinin boy ve ağırlık değerleri; 13,2-21,7 $\mathrm{cm}$ ve 23,21-88,19 g arasında dağılım göstermektedir. Karkas et veriminin dişi, erkek ve genel olarak sirasıyla $\% 72,93 \pm 0,51, \% 71,96 \pm 1,85$ ve $\% 71,77 \pm 1,12$ olduğu ve net karkas et ağırlığının 20,46-62,18 g arasında değiştiği belirlenmiştir. Karadeniz'de 22,5-28 cm boy aralığındaki lüfer balığının \%73,70 net et oranı ile 15 ticari deniz balığı içinde 5 . sırada olduğu bildirilmiştir (Erkoyuncu vd., 1994). Samsun vd. (2006) mezgit balığının et verimini \%45,072-63,078, Çağlak ve Karslı (2013) sudak balığının et verimini mevsimlere göre \% 60,74-67,45, Duman vd. (2011) dağ alabalıklarının et verimini yaş gruplarına göre \% 58,04-61,07, Karaton ve İnanlı (2011) tatlı su kefalinin et verimini yaş gruplarına göre \% 56,15-61,63 olarak belirlemişlerdir. Balıklarda et verimi, balığın türüne, cinsiyetine, yaşına, üreme mevsimine, beslenme durumuna, avlandığı siradaki mide içeriğine göre değişmektedir (Gülyavuz ve Ünlüsayın, 1999).

Etten sonra en büyük kısmı oluşturan kafanın, dişi, erkek ve dişi+erkek bireylerde yüzde oranı sırasıyla \%17,81 $\pm 0,31, \% 17,59 \pm 0,30$ ve $17,69 \pm 0,22$ olarak hesaplanmıştır. Kafa oranı balık büyüklüğüne göre \%11,11-\%21,57 arasında değişmektedir. Tüm

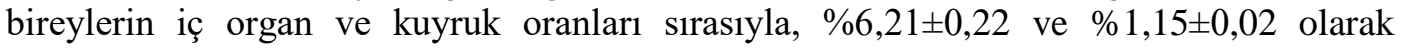
bulunmuştur. Dişi ve erkek lüfer balıklarının, boy, ağırlık ve vücut kısımları arasındaki farklar istatistiki açıdan önemsiz bulunmuştur $(\mathrm{P}>0,05)$. Bu sonuçlara göre $P$. saltatrix 'in vücut kısımlarının toplam ağırlığına oranı, en fazladan en aza doğru sirasıly, karkas et, kafa, iç organ ve kuyruk şeklinde ifade edilebilir. Erkoyuncu vd. (1994), Lüfer balığının iç organ ve kafa oranını sırasıyla \%7,12 ve \%17,54 olarak bildirmiş olup, sonuçlar, bu araştırma sonuçlarıyla uyumlu görülmektedir. Ayrıca, mezgit (Düzgüneş ve Karaçam, 1990; Samsun vd., 2006), palamut (Samsun vd., 2003), kalkan (Samsun vd., 2005), istavrit (Karaçam ve Düzgüneş, 1991), zargana, tirsi, izmarit, kırlangıç ve barbunya (Erkoyuncu vd., 1994; Bilgin vd., 2004) gibi balıklarda etten sonra en büyük k1smı kafanın oluşturduğu bildirilmiştir. Buradan, balıklarda, oranları türlerine göre değişebilmekle birlikte genelde kafanın vücut parçaları içinde etten sonra en büyük kısmı 
teşkil ettiği, diğer vücut kısımlarının ise daha düşük oranlarda bulunduğu sonucuna var1labilir.

Balık boyu ve ağırlığı ile diğer vücut kısımları arasında yüksek korelasyonlu doğrusal ve üssel ilişkilerin olduğu belirlenmiştir. Dağtekin ve Baştürk (2014), gümüşi havuz balığının, balık ağırlığı ile net et, baş, iç organ, yüzgeç, deri ve karkas gibi vücut kısımları arasında yüksek korelasyonlu üssel ilişkiler bildirmişlerdir. Buda balık boyu ve ağırlığı arttıkça, net et oranının da artacağının bir göstergesidir. Nitekim balıkların yavru ve genç bireylerinde genelde et veriminin düşük olduğu, balığın büyüdükçe verimin arttığı, bu nedenle balıkların genç yaşta avlanmaması gerektiği ve et verimi bakımından önemli olduğu ifade edilmiştir (Gülyavuz ve Ünlüsayın, 1999).

Çalışmada örneklerin yaş ağırlıkta ham protein, ham yağ, su ve ham kül miktarı sirasiyla $\% 16,39 \pm 0,234, \% 13,37 \pm 0,088, \% 67,20 \pm 0,465$ ve $\% 1,02 \pm 0,038$ olarak tespit edilmiştir. Kuru madde içeriği ise \% $32,80 \pm 0,465$ olarak bulunmuştur. Farklı bir çalışmada lüfer balığının kimyasal yapısının, \%68,2 su, \%31,8 kuru madde, \%20,8 protein, \%9,2 yağ ve \%1,6 külden oluştuğu bildirilmiştir (Erkoyuncu vd., 1994). Gülyavuz ve Ünlüsayın (1999), Lüfer balığının, su, yă̆ ve protein oranlarını sırasıyla \% 77, \%2,5 ve $\% 19,3$ olarak bildirmişlerdir. Barbun balığı (Mullus barbatus) için ortalama ham protein $\% 14,84 \pm 0,12$, ham yağ $\% 1,75 \pm 0,12$, su $\% 79,00 \pm 0,52$ ve ham kül $\% 1,45 \pm 0,03$ şeklinde bildirilmiştir (Gümüş vd., 2009). Kalay vd. (2008) Liza ramada türü balıkların kas dokusu protein, yağ, nem ve kül ortalamalarını sırasıyla, 16,02-17,66, 0,25-0,47, 80,7082,19 ve 1,25-1,28 olarak belirlemiş ve yaşa bağlı olarak kas dokusu ham protein düzeyinin düştüğünü, ham yağ düzeyinin ise artış gösterdiğini ifade etmişlerdir. İlhan vd., (2006), Sardinella aurita'nın yağ oranı ile su oranının ters orantılı olduğunu, yağ oranının yaz ve sonbahar mevsimlerinde arttığını bildirmişlerdir. Aynı çalışmada protein oranındaki değişimin yağdaki değişimle paralellik gösterdiğini, kimyasal kompozisyondaki değişimlerin yaz ve sonbahar aylarında su sıcaklığının yükselmesine bağlı olarak balığın beslenmesinin daha iyi olmasından kaynaklandığını belirtmişlerdir. Palamut balığ 1 ile ilgili yapılan bir çalışmada ham protein $14,55 \pm 0,69$, ham yağ $12,87 \pm 0,32$, nem $67,71 \pm 0,40$ ve ham kül $1,76 \pm 0,15$ olarak tespit edilmiştir (Koral vd., 2010). Kocatepe vd. (2011), hamsi için ham protein, ham yağ, su ve ham kül değerlerini sırasıly, $22,71 \pm 0,04,10,64 \pm 0,04,62,86 \pm 0,03$ ve $1,48 \pm 0,01$ şeklinde bildirmişlerdir. Buradan yağ miktarının balık büyüklüğü ile önemli değişim gösterdiği görülebilmektedir. Diğer çalışmalarda da lüfer balığının kimyasal kompozisyonunda özellikle protein ve yağ oranları arasındaki farklar dikkat çekmektedir. $\mathrm{Bu}$ farkın; kullanılan balıkların büyüklüklerinin yanında, avlama bölgesi ve avlama mevsimlerinden kaynaklanabileceği düşünülmektedir.

Araştırma sonuçlarına göre lüfer balığının et verimi birçok balık türüne göre yüksektir. Mevcut çalışma ve daha önce yapılan çalışmaların sonuçları değerlendirildiğinde kimyasal kompozisyon, balık büyüklüğüne göre değişiklik göstermektedir. Bu nedenle, ülkemizde pelajik balıklar arasında, yıldan yıla av miktarı azalan ve hem ekonomik hem de besin kompozisyonu bakımından değerli balıkların başında gelen lüfer balığından daha fazla et verimi elde edebilmek ve sürdürülebilirliğini sağlayabilmek açısından, her farklı boy grubundan bireylerde gerekli çalışmalar yapılması, ekonomik boy ve ilk üreme boyunun belirlenerek uygulamaya konulması büyük önem arz etmektedir. 


\section{KAYNAKLAR}

Bal, H., Yanık, T. \& Türker, D. (2015). Length-weight and length-length relationships of the blufish Pomatomus saltatrix (Linnaeus, 1766) population in the South Marmara Sea of Turkey. Alinteri Zirai Bilimler Dergisi, 29(2), 26-33.

Bilgin, S., Samsun, N., Kalaycı, F. \& Samsun, O. (2004). Zargana balığı (Belone belone euxini Günther, 1866) et veriminin mevsim, yaş ve cinsiyete göre değişimi, SDÜ, Eğirdir Su Ürünleri Fakültesi Dergisi, 2(12),1-6.

Cengiz, Ö., Özekinci, U. \& Öztekin, A. (2012). Çanakkale Boğazı ve Gelibolu Yarımadası (Kuzeydoğu Akdeniz, Türkiye) kıyılarında yakalanan lüfer balığının Pomatomus saltatrix, (Linnaeus, 1766) total boy-otolit boyu arasındaki ilişki. I Ĭgdı Üniversitesi, Fen Bilimleri Enstitüsü Dergisi, 2(1),31-34.

Ceyhan, T. \& Akyol, O. (2005). Marmara Bölgesi'nde lüfer (Pomatomus saltatrix L., 1766) avcılığında kullanılan olta takımları. Ege Journal of Fisheries and Aquatic Sciences, 22(34), 351-355.

Ceyhan, T. \& Akyol, O. (2006). Marmara Denizi lüfer (Pomatomus saltatrix L., 1766) balıklarının yaş dağılımı ve çatal boy-otolit boyu arasındaki ilişki. Ege Journal of Fisheries and Aquatic Sciences, 23(1-3),369-372.

Ceyhan, T., Akyol, O. \& Ayaz, A. (2015). Marmara Bölgesi'nde lüfer (Pomatomus saltatrix L., 1766) avcılığında kullanılan alamana ağları. Ege Journal of Fisheries and Aquatic Sciences, 22(3-4),447-450.

Çağlak, E. \& Karslı, B. (2013). Beyşehir Gölü sudak (Sander lucioperca Linnaeus, 1758) balıklarının mevsimsel et verimi ve kimyasal kompozisyonu. S.D.Ü. Ĕgirdir Su Ürünleri Fakültesi Dergisi, 9(1), 1-8.

Çelikkale, M.S., Kurtoğlu I.Z. \& Şahin, S. (1998). Comparision of the composition and biochemical properties of meat of rainbow trout (Oncorhynchus mykiss) and brook trout (Salvelinus fontinalis Mitchill, 1814), (in Turkish). Atatürk Üniversitesi, Ziraat Fakültesi, Doğu Anadolu Bölgesi, III. Su Ürünleri Sempozyumu, 10-12 Haziran, Erzurum, 41-49.

Dağtekin, B.B. \& Baştürk, Ö. (2014). Çıldır Gölü’nde yaşayan gümüşi havuz balığının (Carassius gibelio bloch, 1782) et verimi ve biyokimyasal kompozisyonu. Yunus Araştırma Bülteni (2), 15-22.

Duman, M., Dartay, M. \& Yüksel, F. (2011). Munzur Çayı (Tunceli) dağ alabalıkları Salmo trutta macrostigma (Dumeril, 1858)'nin et verimi ve kimyasal kompozisyonu. Firat Üniversitesi Fen Bilimleri Dergisi, 23(1),41-45.

Düzgüneş, E. \& Karaçam, H. (1990). Doğu Karadeniz' deki mezgit (Gadus euxinus Nord., 1840) balıklarında bazı populasyon parametreleri, et verimi ve biyokimyasal kompozisyonu, Doğa Turkish Journal of Zoology, 14, 345-352.

Ergül, U. (1970). Balığın gıda değeri. Türk Veteriner Hekimleri Derneği Dergisi, 40(3),32-35.

Erkoyuncu, İ., Erdem, M., Samsun, O., Özdamar, E. \& Kaya, Y. (1994). Karadeniz'de avlanan bazı balık türlerinin et verimi, kimyasal yapısı ve boy-ağırlık ilişkisinin belirlenmesi üzerine bir araştırma, İstanbul Üniversitesi, Su Ürünleri Dergisi, 8(1-2), 181-191.

FAO, 2000. Fishstat Plus: Universal Software for Fishery Statistical Time Series Version 2.3. FAO Fisheries Department, Fishery Information, Data and Statistics Unit. Rome.

Göktürk, D., Deniz, T., Yılmaz, S. \& Sacıhan, S.D. (2017). Balıkçılıkta yasak av boyu problemi: İstanbul'da satışa sunulan balıkların uygunluğunun incelenmesi. Ecolojical Life Sciences (NWSAELS), 12(1),1-15.

Göğüş, A.K. \& Kolsarıc1, N. (1992). Su ürünleri teknolojisi, Ankara Üniversitesi Ziraat Fakültesi Yay. Ankara.

Gülyavuz, H. \& Ünlüsayın, M. (1999). Su Ürünleri İşleme Teknolojisi. Ders Kitabı. SDÜ Eğirdir Su Ürünleri Fakültesi, Isparta, 366s. 
Gümüş, B., İkiz, R., Ünlüsayın, M. \& Gülyavuz, H. (2009). Barbun balığı (Mullus barbatus)'nın sıcak dumanlama sonrası besin bileşenlerindeki değişimler. Ístanbul Üniversitesi Su Ürünleri Dergisi, 24, 15-24.

Gürtan, G. (1959). Pomatomus saltatrix L. (Lüfer balıkları)'nın biyolojisi hakkında. Hidrobiyoloji Mecmuası, İstanbul Üniversitesi Fen Fakültesi, Hidrobiyoloji Araştırma Enstitüsü Yayinlart, 5(1-4), 144-184.

İlhan, R., İkiz, R. \& Gülyavuz, H. (2006). Antalya Körfezi'den avlanan Sardinella aurita (Valenciennes, 1847)'nın et kompozisyonunun mevsimsel değişimi. Ege Journal of Fisheries and Aquatic Sciences, 23(1-3),439-442.

Kalay, M., Sangün, M.K., Ayas, D. \& Göçer, M. (2008). Chemical composition and some trace element levels of thinlip mullet, Liza ramada caught from Mersin Gulf. Ekoloji, 17, 11-16.

Karaçam, H. \& Düzgüneş, E. (1991). Some population aspects, mealt yield and biochemical composition of Mediterranean horse mackerel, Trachurus mediterranius (Steindacher, 1968) in the Black Sea, Doğa Turkish Journal of Zoology, 15, 195-201.

Karaton, N. \& İnanl1, A.G. (2011). Tatl1 su kefali (Squalius cephalus)'nin et verimi ve besin bileşimine mevsimsel değişimin etkisi. Fırat Üniversitesi Fen Bilimleri Dergisi, 23, 63-69.

Kocatepe, D., Turan, H., Taşkaya, G., Kaya, Y., Erden, R. \& Erdoğdu, F. (2011). Effects of cooking methods on the proximate composition of Black Sea anchovy (Engraulis encrasicolus, Linnaeus 1758). Glda, 36(2),71-75.

Koral, S., Köse, S. \& Tufan, B. (2010). The effect of storage temperature on the chemical and sensorial quality of hot smoked Atlantic bonita (Sarda sarda, Bloch, 1838) packed in aluminium foil. Turkish Journal of Fisheries and Aquatic Sciences, 10, 439-443.

Korkut, A.Y. \& Hoşsu, B. (1998). Balık Besleme ve Yem Teknolojisi II. Ege Üniversitesi Su Ürünleri Fakültesi Yayınları No:54, Ders Kitabı Dizin No:23, 250s.

Özdemir, S., Erdem, E., Birinci Özdemir, Z. \& Şahin, D. (2009a). Karadeniz'de avlanan pelajik türlerden istavrit (Trachurus trachurus), lüfer (Pomatomus saltatrix) ve tirsi (Alosa alosa) balıklarının boy kompozisyonundan populasyon parametrelerinin tahmini. Firat Üniversitesi Fen Bilimleri Dergisi, 21(1), 1-8.

Özdemir, S., Erdem, Y., Erdem, E. \& Birinci Özdemir, Z. (2009b). Dip trolü ile farklı av sahalarında avlanan karagöz istavrit (Trachurus trachurus, L.), lüfer (Pomatomus saltatrix, L.) balıklarının av verimi ve boy kompozisyonlarının karşılaştırılması. Celal Bayar Üniversitesi Fen Bilimleri Dergisi, 5(1), 19-26.

Samsun, N., Samsun, O., Bilgin, S. \& Kalayc1, F. (2003). Sinop yöresinde küçük balıkçılar tarafından avlanan palamut (Sarda sarda Bloch, 1758) balığının av kompozisyonu ve et veriminin araştırılması, XII. Ulusal Su Ürünleri Sempozyumu (2-5 Eylül 2003) Bildiriler Kitabı, Fırat Üniversitesi Su Ürünleri Fakültesi, Elazığ ; 506-511.

Samsun, N., Samsun, O. \& Kalaycı, F. (2005). Sinop bölgesinde (Karadeniz) avlanan kalkan (Scophthalmus maeoticus Pallas, 1811) balığının et verimi ile protein ve yağ oranlarının mevsimsel değişimi, Fırat Üniversitesi Fen ve Mühendislik Bilimleri Dergisi, 17(4),629635.

Samsun, S., Erdem, M.E. \& Samsun, N. (2006). Mezgit (Gadus merlangus euxinus Nordmann, 1840) balığının et verimi ve kimyasal kompozisyonunun belirlenmesi, Fırat Üniversitesi Fen ve Mühendislik Bilimleri Dergisi, 18 (2), 165-170.

Sümbüloğlu, K. \& Sümbüloğlu, V. (2000). Biyoistatistik. Hatipoğlu Yayınları: 53, Ankara, 269s.

Sümer, Ç., Özdemir, S. \& Erdem, Y. (2010). Farklı göz açıklıklarında monoflament ve multiflament galsama ağlarının lüfer balığı (Pomatomus saltatrix L., 1766) için seçiciliğinin hesaplanmas1. Ege Journal of Fisheries and Aquatic Sciences, 27(3),121-124.

Tekinay, A.A., Alpaslan, M., Özen, Ö., Akyüz, P.E., Kahyaoğlu, G. \& Güroy, D. (2003). A comparative analysis of Istanbul fish market records between 1998 and 2001. Ege Journal of Fisheries and Aquatic Sciences, 20(3-4),413-418.

TÜİK 2015. Su Ürünleri İstatistikleri. Türkiye İstatistik Kurumu, Ankara. 
Yıldız, M., Şener, E. \& Fenerci, S. (2000). Gökkuşağı alabalığı (Oncorhynchus mykiss) ve deniz levreği (Dicentrarchus labrax)'nin yağ asidi ihtiyacı ve vücut yağı kompozisyonu, Su Ürünleri Sempozyumu, Sinop (20-22 Eylül 2000), 574-587. 